\title{
New Miocene Carnivora (Mammalia) from Moruorot and Kalodirr, Kenya
}

\author{
Brent Adrian, Lars Werdelin, and Aryeh Grossman
}

\begin{abstract}
We describe new carnivoran fossils from Kalodirr and Moruorot, two late Early Miocene sites in the Lothidok Formation of West Turkana, Kenya. The fossils include a new species of viverrid, Kichechia savagei sp. nov., a new genus and species of felid, Katifelis nightingalei gen. et sp. nov., and an unidentified musteloid. We also report new records of the amphicyonid Cynelos macrodon. These new fossils increase the known diversity of African Early Miocene carnivorans and highlight regional differences in Africa.
\end{abstract}

Brent Adrian, M.F.A., Department of Anatomy, Midwestern University, 19555 North 59th Avenue, Glendale, Arizona, USA, 85308. badria@midwestern.edu

Lars Werdelin, Ph.D., Department of Palaeobiology, Swedish Museum of Natural History, Box 50007, SE104 05, Stockholm, Sweden. werdelin@nrm.se Aryeh Grossman, Ph.D., Department of Anatomy, Midwestern University, 19555 North 59th Avenue, Glendale, Arizona, USA, 85308. agross@midwestern.edu

Keywords: Early Miocene; Kenya; carnivorans; Lothidok Formation; new genus; new species

Submission: 28 April 2017 Acceptance: 16 March 2018

\section{INTRODUCTION}

Current models indicate that Carnivora dispersed into Africa following the collision of the Eurasian and Afro-Arabian plates near the OligoceneMiocene boundary. The earliest unequivocal African record of carnivorans is from the earliest Early Miocene site of Nakwai, West Turkana, northern Kenya, dated 23 Ma-15 Ma (Grossman and Holroyd, 2009; Rasmussen and Gutiérrez, 2009;
Reynoso, 2014). Overall, however, Early Miocene records of carnivorans in the Turkana Basin are scarce (Savage, 1965; Anyonge, 1991; Werdelin and Peigné, 2010; Leakey et al., 2011; Grossman et al., 2014), and little material has been described. Currently known carnivorans from West Turkana include representatives of genera and species also present elsewhere, particularly in the Hiwegi Formation of Rusinga Island, western Kenya (Collinson et al., 2009; Maxbauer et al., 2013) (Figure

http://zoobank.org/E9479CE8-5D30-44E1-8474-322EB1C09B59

Adrian, Brent, Werdelin, Lars, and Grossman, Aryeh. 2018. New Miocene Carnivora (Mammalia) from Moruorot and Kalodirr, Kenya. Palaeontologia Electronica 21.1.10A 1-19. https://doi.org/10.26879/778

palaeo-electronica.org/content/2018/2164-new-kenyan-miocene-carnivora

Copyright: March 2018 Society of Vertebrate Paleontology.

This is an open access article distributed under the terms of the Creative Commons Attribution License, which permits unrestricted use, distribution, and reproduction in any medium, provided the origial author and source are credited.

creativecommons.org/licenses/by/4.0/ 


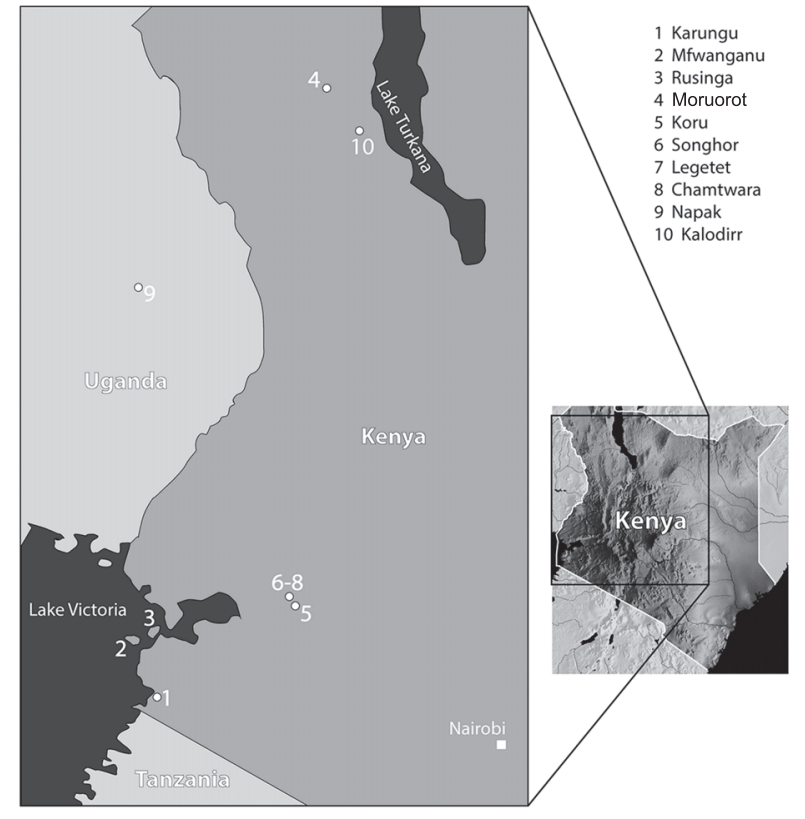

FIGURE 1. Known carnivoran localities in western Kenya and eastern Uganda.

1). Rusinga has a time-averaged collection sampling different localities ranging approximately between $20 \mathrm{Ma}$ and $17 \mathrm{Ma}$ (Peppe et al., 2017). Among carnivorans common to the Turkana Basin and western Kenya, Savage (1965) included fossils from Moruorot, West Turkana, in his hypodigm of Kichechia zamanae, the most common small viverrid in the Early Miocene eastern African sites. Werdelin and Peigné (2010) report Ki. zamanae from Moruorot and Kichechia sp. from Kalodirr. The amphicyonid Cynelos macrodon is recognized from West Turkana at Kalodirr (Werdelin and Peigné, 2010) as well as Moruorot (Leakey et al., 2011) (Figure 1). However, most of the carnivoran material from West Turkana remains undescribed.

In this work, we describe previously unpublished carnivoran fossils from Moruorot and Kalodirr, two late Early Miocene (Burdigalian) sites within the Lothidok Formation of West Turkana (Figure 1), dated to $17.5( \pm 0.2) \mathrm{Ma}-16.8( \pm 0.2)$ Ma (Boschetto et al., 1992). The new material allows us to identify viverrid fossils previously assigned to the hypodigm of Ki. zamanae as a new species (Figure 2), as well as recognize a new genus and species of small felid and a new, indeterminate musteloid. Additionally, the new fossils contribute important information about the dentition of Cy. macrodon, previously known from very few teeth. While overall still similar to the Rusinga Island fauna, the carnivorans from Kalodirr and Moruorot show distinctive features and highlight the diversity of Carnivora in various regions of eastern Africa in the Early Miocene. It is likely that the geographic distance between West Turkana and Rusinga Island (Figure 1), as well as a difference in absolute age, account for the regional differences among sites (Grossman et al., 2014), but we cannot rule out environmental differences as well (Hill et al., 2013).

\section{Stratigraphic and Geographic Provenience}

The localities of Kalodirr and Moruorot Hill are located within the Kalodirr Member (Lothidok Formation), between the Kalodirr and Naserte tuffs on the west side of Lake Turkana in Kenya (Figure 1). Kalodirr is located near the head-waters of the Kalodirr River $\left(3^{\circ} 20^{\prime} \mathrm{N}, 35^{\circ} 45^{\prime} \mathrm{E}\right)$, extending from just south of the Lodwar-Kalakol road north to the Lokipenata Ridge (Leakey and Leakey, 1986a; Leakey and Leakey, 1986b; Boschetto et al., 1992; Grossman and Holroyd, 2009). Moruorot lies south of the Lodwar-Kalakol road and comprises two contemporaneous localities (Madden, 1972; Boschetto et al., 1992) (Figure 1). The age of the Kalodirr fauna is well constrained based on $\mathrm{K}-\mathrm{Ar}$ analysis of the underlying Kalodirr tuff (17.5 \pm 10.2 $\mathrm{Ma})$ and the overlying Naserte tuff $(16.8 \pm 0.2 \mathrm{Ma})$. Sedimentological analyses indicate that deposition occurred via small meandering stream channels (Boschetto et al., 1992). Environmental reconstructions based on mammalian faunas indicate that the site was probably a closed to open woodland habitat (Grossman and Holroyd, 2009). Further support for this interpretation is provided by broad-leaved plant fossils from the site, some possessing an acuminate tip ('drip tip'), which indicates seasonally wet conditions (Boschetto et al., 1992, Collinson et al., 2009). The presence of lacustrine or fluvial water is further indicated by fossils of aquatic species, such as a pelomedusid turtle, crocodilians, and fish (Grossman and Holroyd, 2009).

\section{MATERIALS AND METHODS}

Measurements of the specimens were taken with digital calipers to the nearest $0.01 \mathrm{~mm}$ and rounded to the nearest $0.1 \mathrm{~mm}$. Lower dentition tooth abbreviations are in lower case (e.g. p3, m2), while upper dentition abbreviations are in upper case (e.g. P3, M2). Measurements of the teeth include length $(L)=$ maximum mesiodistal distance of the tooth along its long axis; and width $(\mathrm{W})=$ maximum buccolingual distance of the tooth perpendicular to the long axis. Angles were measured using a 6" C-Thru clear plastic protractor on high quality photographs. The graphs in Figure 3.1 were 

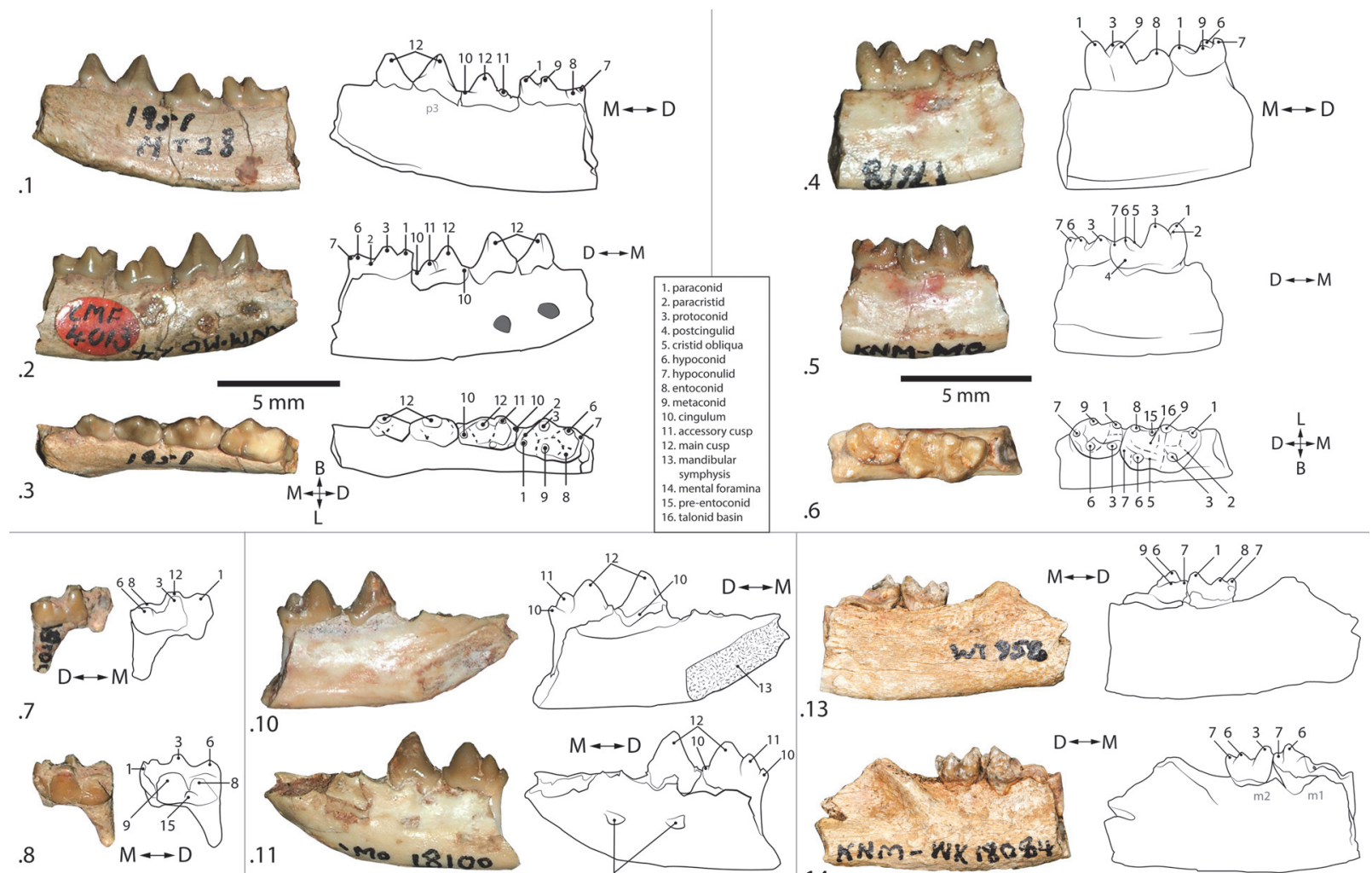

.7
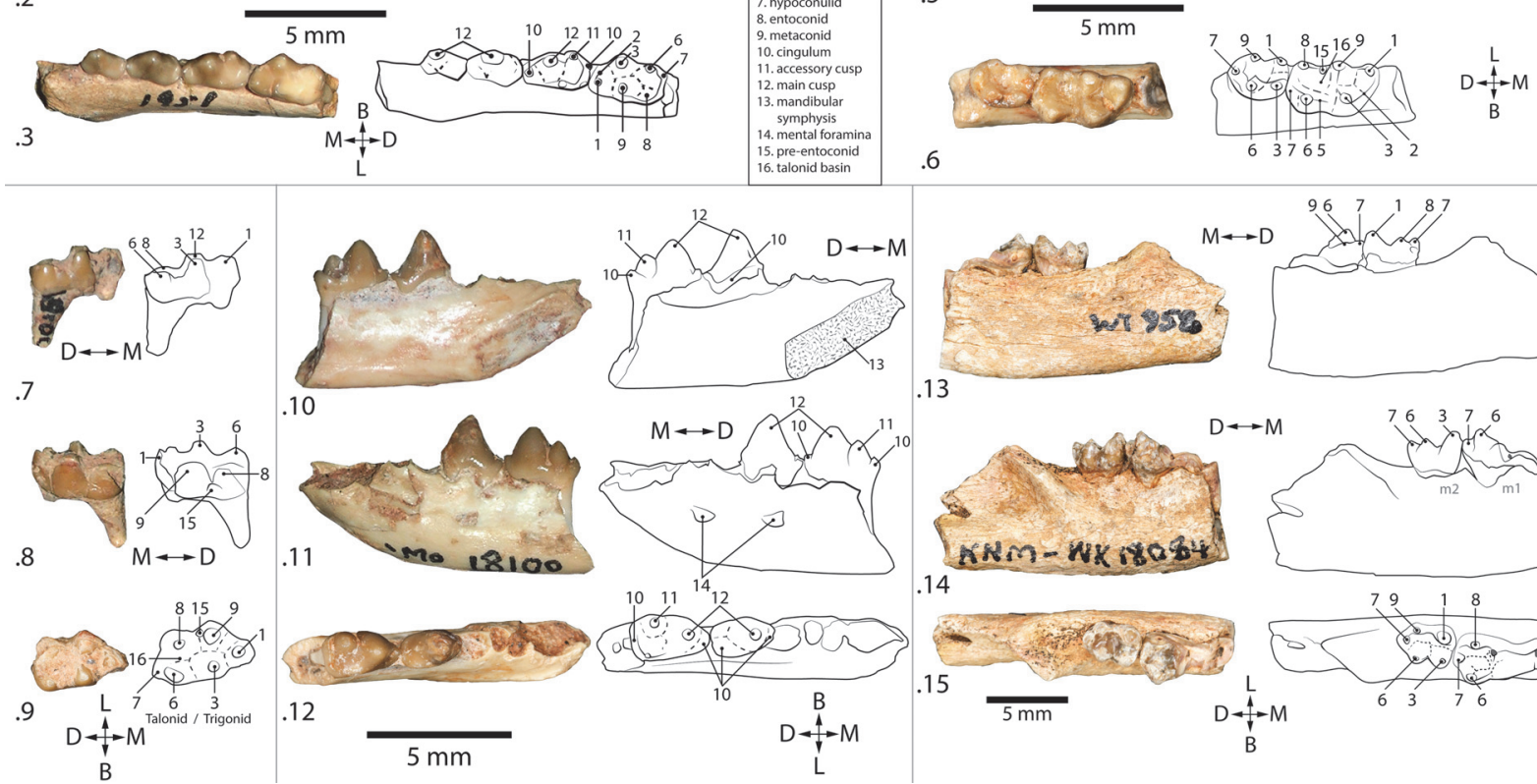

FIGURE 2. Kichechia savagei sp. nov. 2.1-3: (top to bottom) lingual, buccal and occlusal views of right mandibular fragment with p2-m1, KNM-MO24 (holotype); 2.4-6: (top to bottom) lingual, buccal, and occlusal views of right mandibular fragment with $\mathrm{m} 1-2$, KNM-MO17118; 2.7-9: (top to bottom) lingual, buccal and occlusal views of right $\mathrm{m} 1$, KNM-MO18100B; 2.10-12: (top to bottom) lingual, buccal, and occlusal views of left mandibular fragment with p3-4, KNM-MO18100A; 2.13-15: (top to bottom) lingual, buccal and occlusal views of right mandibular fragment with $\mathrm{m} 2$ and broken $\mathrm{m} 1$, KNM-WK18084.

made in AabelNG v.4 (Gigawiz, Ltd.). A phylogenetic analysis of extant and fossil viverrids and herpestids was conducted using 25 dental characters described in Morales and Pickford (2011). We used an updated version of the Morales and Pickford (2011) data set as our starting point, but we scored and added Kichechia savagei sp. nov. (Appendices 1-2). Following Morales and Pickford (2011), the hypercarnivorous herpestid Crossarchus obscurus was used as an outgroup. Species were selected from the matrix if their characters could be applied to the new specimens included in this study. A maximum parsimony analysis was conducted in Tree Analysis using New Technology (TNT) v. 1.5 (Goboloff and Catalano, 2016), using implicit enumeration. All characters were equally weighted and unordered. Tree length, consistency index $(\mathrm{Cl})$, and retention index $(\mathrm{RI})$ were recorded.

\section{Institutional and Site Abbreviations}

AD, Arrisdrift (Namibia); CA, Chamtwara (Kenya); CMF, Coryndon Museum Fossils (National Museums of Kenya, Nairobi); IPS, Catalan Institute of Palaeontology Miquel Crusafont (Sabadell, Spain); KNM, National Museums of Kenya (Nairobi, Kenya); MO, Moruorot (Kenya); NHMUK, Natural History Museum (all have the prefix M) (London, UK); RU, Rusinga Island (Kenya); WK, Kalodirr (Kenya).

\section{SYSTEMATIC PALAEONTOLOGY}

Order CARNIVORA Bowditch, 1821 Suborder FELIFORMIA Kretzoi, 1945 

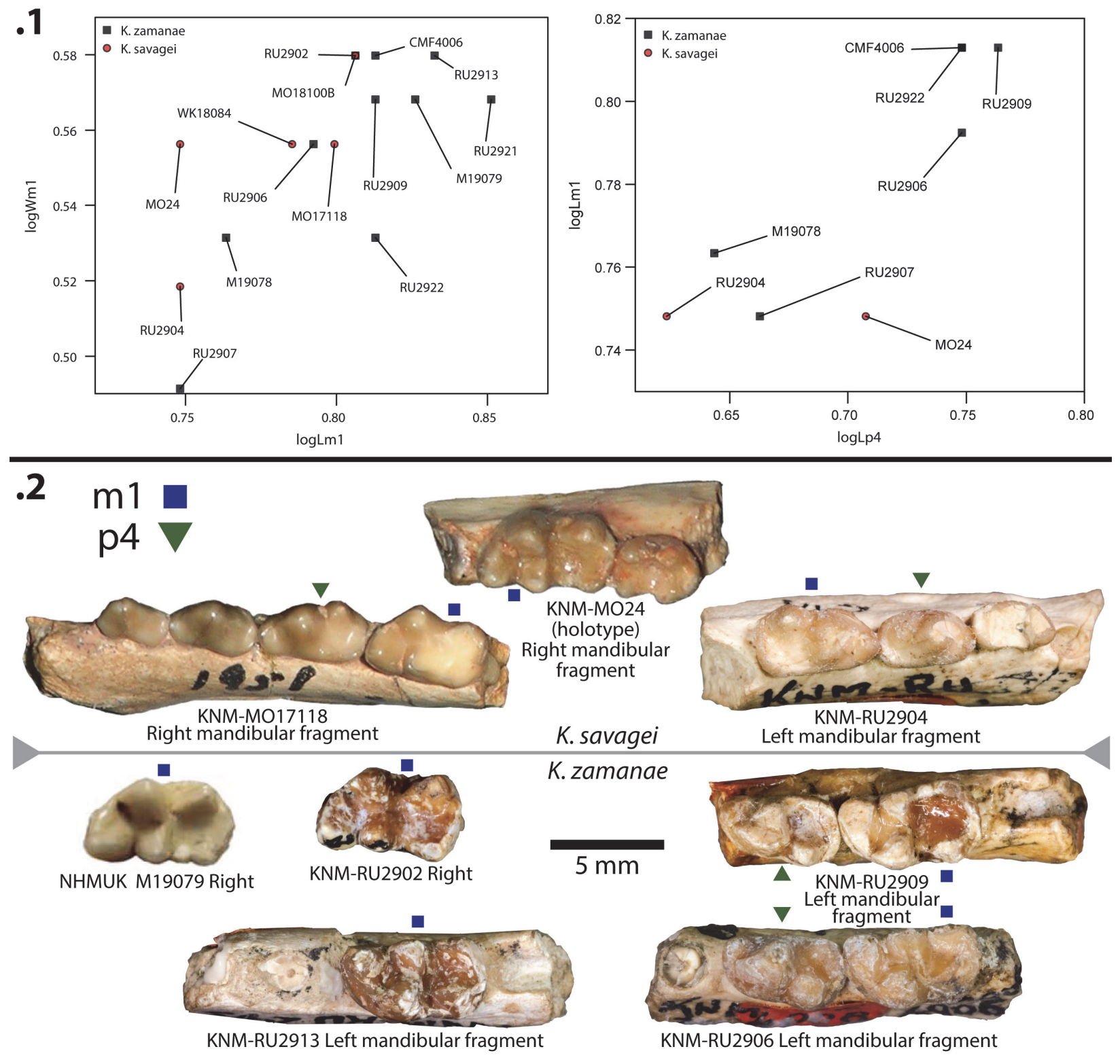

FIGURE 3.1. Scatter plot showing the lengths and widths (logarithmic scale, in $\mathrm{mm}$ ) of the $\mathrm{p} 4$ and $\mathrm{m} 1$ of Kichechia savagei sp. nov. and Ki. zamanae. 3.2. Occlusal views of referred teeth in graph.

Family VIVERRIDAE Gray, 1821 Subfamily PARADOXURINAE Gray, 1864

Genus KICHECHIA Savage, 1965

Kichechia savagei sp. nov.

Figures 2-4; Table 1; Appendices 1, 2 zoobank.org/322113B2-2169-445A-8FF1-DEF840CFC369

Holotype. Right mandibular fragment with p2-m1 (KNM-MO24).

Other type specimens. Right mandibular fragment with m1-2 (KNM-MO17118); right m1 (KNMMO18100B); left mandibular fragment with p3-4 (KNM-MO18100A); right mandibular fragment with m2 and broken m1 (KNM-WK18084).
Type locality. Moruorot, Kalodirr Member, Lothidok Formation, Kenya. Early Miocene.

Synonymy. Kichechia zamanae partim. (Savage, 1965).

Age. $17.5 \pm 0.2 \mathrm{Ma}-16.8 \pm 0.2 \mathrm{Ma}$.

Derivatio nominis. The specific name is in honor of the work of Professor R.J.G. Savage.

\section{Diagnosis}

Kichechia savagei sp. nov. is a paradoxurine viverrid similar to Ki. zamanae (Savage, 1965: figures 58-60) with a mandibular dental formula of (-, $1,4,2)$. The main cuspid of p2 of Ki. savagei sp. 


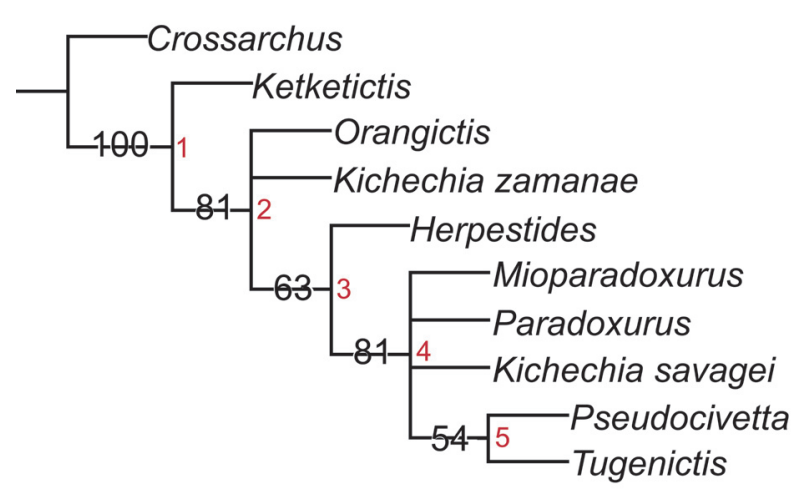

FIGURE 4. Phylogenetic tree using majority rule (50 \%) consensus tree of 11 minimum length trees: Length $=37$; Consistency Index $(\mathrm{Cl})=0.59$; Retention Index $(\mathrm{RI})=$ 0.53 . Nodes are indicated in red. nov. is higher relative to p3 and angles less mesially than in Ki. zamanae (Figure 2.1-2). The distal cingulum of p2 and p3 is flatter and less extensive in Ki. savagei sp. nov. than in Ki. zamanae (Figure 2.1-2). The main cuspid of $p 4$ is taller and the accessory cuspid less tilted distally in Ki. savagei sp. nov. than in Ki. zamanae (Figure 2.1-2, 10-11). The main cuspid of the $\mathrm{p} 4$ of $K i$. savagei sp. nov. is positioned more mesially relative to the accessory cuspid than in Ki. zamanae (Savage, 1965: figure 58) (Figure 2.1-3). The cuspids of Ki. savagei sp. nov. are lower and rounder than in Ki. zamanae, particularly the molar hypoconulids (Figure 2.1-9, 13-15). The trigonid cuspids of the $m 1$ are of equal height in Ki. savagei sp. nov. (Figure 2.1-2, 4-5, 7$8)$, whereas in Ki. zamanae, the protoconid is tall-

TABLE 1. Measurements of the lower dentition of specimens of Kichechia. All measurements by the authors except $\left.{ }^{*}\right)$, measurements from Savage (1965).

\begin{tabular}{|c|c|c|c|c|c|c|c|c|c|c|c|c|}
\hline Taxon & Site & Specimen & Lp2 & Wp2 & Lp3 & Wp3 & Lp4 & Wp4 & Lm1 & Wm1 & Lm2 & Wm2 \\
\hline \multirow[t]{6}{*}{ Kichechia savagei sp. nov. } & Moruorot & $\begin{array}{l}\text { KNM-MO24 } \\
\text { (holotype) }\end{array}$ & 3.4 & 1.9 & 4.1 & 2.4 & 5.1 & 2.8 & 5.6 & 3.6 & & \\
\hline & Moruorot & KNM-MO17118 & & & & & & & 6.3 & 3.6 & 3.9 & 3.0 \\
\hline & Moruorot & KNM-MO18100A & & & 4.2 & 2.5 & 5.2 & 3.1 & & & & \\
\hline & Moruorot & KNM-MO18100B & & & & & & & 6.4 & 3.8 & & \\
\hline & Kalodirr & KNM-WK18084 & & & & & & & 6.1 & 3.6 & 3.9 & 2.9 \\
\hline & Rusinga & KNM-RU2904 & & & 3.9 & 2.1 & 4.2 & 2.6 & 5.6 & 3.3 & & \\
\hline \multirow[t]{19}{*}{ Kichechia zamanae } & Rusinga & KNM-RU2902 & & & & & & & 6.4 & 3.8 & & \\
\hline & Rusinga & KNM-RU2905 & & & & & 6.4 & 3.1 & & & & \\
\hline & Rusinga & KNM-RU2906 & & & & & 5.6 & 3.3 & 6.2 & 3.6 & & \\
\hline & Rusinga & KNM-RU2907 & & & 3.6 & 2.0 & 4.6 & 2.7 & 5.6 & 3.1 & & \\
\hline & Rusinga & KNM-RU2909 & & & & & 5.8 & 3.2 & 6.5 & 3.7 & & \\
\hline & Rusinga & KNM-RU2912 & & & 4.9 & 2.5 & & & & & & \\
\hline & Rusinga & KNM-RU2913 & & & & & & & 6.8 & 3.8 & & \\
\hline & Rusinga & KNM-RU2916 & & & & & 5.6 & 3.6 & & & & \\
\hline & Rusinga & KNM-RU2920 & 3.6 & 2.0 & 3.8 & 2.0 & & & & & & \\
\hline & Rusinga & KNM-RU2921 & & & & & & & 7.1 & 3.7 & & \\
\hline & Rusinga & KNM-RU2922 & & & 4.6 & 2.5 & 5.6 & 2.5 & 6.5 & 3.4 & & \\
\hline & Rusinga & KNM-RU2923 & & & & & 5.9 & 3.6 & & 3.8 & & \\
\hline & Rusinga & KNM-RU2924 & & & & & & & & 4.3 & & \\
\hline & Rusinga & KNM-RU2925 & & & 4.2 & 2.2 & 5.4 & 3.0 & & & & \\
\hline & Rusinga & KNM-RU15997 & & & & & & & & 4.6 & & \\
\hline & Rusinga & $\begin{array}{l}\text { KNM-RU--- } \\
\text { (CMF4006) }\end{array}$ & & & 3.8 & 2.1 & 5.6 & 3.3 & 6.5 & 3.8 & & \\
\hline & Rusinga & $\begin{array}{l}\text { NHMUK M19078 } \\
\text { (holotype) }^{*}\end{array}$ & & & 3.6 & 2.4 & 4.4 & 2.9 & 5.8 & 3.4 & & \\
\hline & Rusinga & NHMUK M19079* & & & & & & & 6.7 & 3.7 & & \\
\hline & Rusinga & NHMUK M19080* & & & & & & & & & 4.0 & 2.8 \\
\hline
\end{tabular}


est, followed by the paraconid, and then the metaconid. There is no crenulated cingulum on the lingual border of the $\mathrm{m} 1$ talonid in Ki. savagei $\mathrm{sp}$. nov., unlike in Ki. zamanae (Savage, 1965: figures 58,60 ) (Figure 2.4, 6-7, 9). The $\mathrm{m} 1$ metaconid of $K i$. savagei sp. nov. covers a larger occlusal area than in Ki. zamanae (Savage, 1965; figure 60) (Figure 2.7-9). The distal border of the $\mathrm{m} 2$ talonid is less rounded and taller relative to the trigonid in $\mathrm{Ki}$. savagei sp. nov. than in Ki. zamanae (Savage, 1965: figures 58-60) (Figure 2.4-6, 13-15).

\section{Description}

The p2 of the holotype of Ki. savagei sp. nov. (KNM-MO24) is a rounded triangular tooth and leans slightly mesially with a mesial edge of $120^{\circ}$ and a distal edge of $60^{\circ}$, when viewed lingually (Figure 2.1-2). The p3 is slightly taller, also has a triangular profile, a mesial edge of $130^{\circ}$ and a distal edge of $70^{\circ}$ in lingual view (Figure 2.1-2). Toward the base of the tooth, the distal and mesial edges slope to slightly curve distally (Figure 2.1-2). The p4 is the longest, widest, and lowest premolar, with a mesial edge of approximately $120^{\circ}$ when viewed lingually. Its distal edge slopes at $60^{\circ}$, and gives rise to a low, rounded accessory cuspid (Figure 2). The mesial and distal edges of the tooth terminate in wide, flat cingula (Figure 2.1-2). The $\mathrm{m} 1$ is the largest tooth of the lower dentition, with a distinct trigonid and talonid. It has a paraconid with a vertical mesial edge and flattened tip (Figure 2.12 ). The protoconid is barely taller than the paraconid and connects to a tall paracristid (Figure 2.2-3). The metaconid is the lowest cuspid of the trigonid and lies directly lingual to the protoconid (Figure 2.3). The $\mathrm{m} 1$ talonid basin is lower, broad, and flat, and has a small but distinct hypoconid and entoconid (Figure 2.1-3); it curves slightly dorsally and ends in a hypoconulid with a flattened tip (Figure 2.1-2).

In the $\mathrm{m} 1$ of KNM-MO17118, the cuspids of the trigonid are equal in height and there is a lower trigonid basin (Figure 2.4-5). The protoconid and paraconid are connected by a wedge-shaped paracristid that is taller than any features of the talonid (Figure 2.4-5). The $\mathrm{m} 1$ protocristid forms a distinctly steep edge against the talonid basin (Figure 2.4). The most robust feature of the talonid is the hypoconid, which is slightly taller than the entoconid (Figure 2.4-5). Both are taller than the inconspicuous, rounded hypoconulid (Figure 2.5-6). A low postcingulid extends along the distal third of the buccal border of the $\mathrm{m} 1$ hypoconid (Figure 2.5). The cristid obliqua is distinct and courses mesially from the hypoconid to the protoconid, allowing for a broad talonid basin (Figure 2.5-6). The protoconid and metaconid are clearly separate in the $\mathrm{m} 2$ of KNM-MO17118 and KNM-WK18084 and the hypoconid and hypoconulid are well marked (Figure 2.4-6, 13-15).

Specimen KNM-MO18100B is damaged and consists of a wide $\mathrm{m} 1$ trigonid with three flattened cuspids of approximately the same height (Figure 2.7-9) and a talonid of approximately the same length and width as the trigonid, though the metaconid projects farthest lingually (Figure 2.9). The entire talonid is very similar to that of the $\mathrm{m} 1$ of KNM-MO17118, with a wide metaconid and protoconid. The $\mathrm{m} 1$ also has a small distally protruding hypoconulid and thin cingulum lying distobuccal to the entoconid (Figure 2.7-9), and is smaller and considerably more damaged in KNM-MO18100B. Like KNM-MO17118, the m1 of KNM-MO18100B has a pre-entoconid on the lingual edge of the crown, between the metaconid and entoconid (Figure 2.8-9). Both specimens have a protoconid and metaconid of equal height, a distinct entoconid and hypoconid, and a small hypoconulid (Figure 2.4-9). The mandibular symphysis of KNM-MO18100A is rectangular in lingual view and relatively shallow dorsoventrally, extending distally to p2 at a $30^{\circ}$ angle (Figure 2.10). There are mental foramina ventral to the distobuccal root of $\mathrm{p} 2$ and the main cusp of p3 (Figure 2.11). Alveoli are preserved in KNM-MO18100A, though the crowns of the canine, incisors, and first two premolars are not preserved (Figure 2.10-12).

The p4 of KNM-MO18100A is similarly triangular in buccal and lingual views (Figure 2,10-11), but the main cuspid is lower and more rounded. It has two cingula: one distal and another very small mesially, with an accessory cuspid that extends to approximately half the height of the main cuspid of p3 (Figure 2.10-12). The p3 is not preserved in KNM-MO17118 (Figure 2.4-6) and is asymmetrical in KNM-MO18100A (Figure 2.10-12). In KNM$\mathrm{MO18100A}$, the $\mathrm{p} 3$ has a single pointed cuspid with a mesial edge of $60^{\circ}$ and a slightly concave distal edge of $120^{\circ}$ in buccal view (Figure 2.8). The distal end of the $\mathrm{p} 3$ expands buccolingually to form a broad talonid basin (Figure 2.9), and there is a slight flattening of the distal and mesial edges of the tooth base, forming a subtle cingulum (Figure 2.7-8). The p1 and p2 are unknown in KNMMO18100A, though the alveoli suggest smaller teeth than the intact premolars (Figure 2.12). A canine alveolus is preserved only in KNM$\mathrm{MO} 18100 \mathrm{~A}$, and suggests that the tooth was rela- 
tively robust and somewhat procumbent (Figure 2.10-12).

Specimens KNM-WK18084 and KNMMO17118 have a complete $\mathrm{m} 2$, with equally tall protoconid and metaconid (Figure 2.4-6, 13-15). The talonid is lower and approximately as wide as the trigonid, with a hypoconid that is slightly taller than the entoconid and the hypoconulid (Figure 2.13-14). The talonid has a wide basin that terminates distally in a rounded, occlusally symmetrical hypoconulid (Figure 2.13-15). The $\mathrm{m} 2$ has a thin distal cingulum along its mesiolingual edge (Figure 2.13). The $m 1$ is broken at the mesial edge of the talonid. It is much longer mesiodistally than the $\mathrm{m} 2$ and only its distal third is intact (Figure 2.13-15). Its hypoconid is taller than its broken entoconid, and it has a short, rounded hypoconulid (Figure 2.13-15).

\section{Discussion}

During analysis of the fossil material from Kalodirr and Moruorot, West Turkana, Kenya, four specimens previously assigned to Kichechia zamanae by Schmidt-Kittler (1987) were reassigned to Ki. savagei sp. nov. One of these (KNMMO24; Figure 2.1-3) was previously part of the hypodigm of Ki. zamanae (Savage, 1965) and is now the holotype of the new taxon. Kichechia zamanae is known from the eastern African Early Miocene and is the most common small carnivoran found in many localities, but these are mostly localities from the Early Miocene of Rusinga Island. The species is also recognized at Songhor, while Kichechia sp. is identified from Karungu in Kenya and perhaps Napak in Uganda (Werdelin and Peigné, 2010) (Figure 1). Figure 3 and Table 1 show the measurements of specimens of Ki. zamanae and $K i$. savagei sp. nov. that occur at Moruorot and Rusinga.

The bunodont character of the teeth of $\mathrm{Ki}$. zamanae first received attention from Savage, who thought its morphology was close to that of the extant Bdeogale and included the fossil genus in the subfamily Herpestinae (Savage, 1965), then a subfamily of Viverridae. Schmidt-Kittler (1987) agreed with Savage (1965) but did not assign it to a subfamily. Schmidt-Kittler (1987) further assigned some material originally described by Savage (1965) as Kichechia to other genera (Morales et al., 2008). This attention has made Ki. zamanae one of the best known small carnivorans from the Early Miocene of Africa, and it was placed in the Viverridae, subfamily Paradoxurinae, by Morales and Pickford (2011). Morales et al. (2001) discussed similarities between the dentitions of Kiche- chia and Orangictis gariepensis (Morales et al., 2001) from Arrisdrift (Namibia) - primarily the overall robust dentition, morphology of the premolars, and the trigonid of $\mathrm{m} 1$ (Morales and Pickford, 2011). Kichechia, like O. gariepensis, is decidedly primitive and has a differentiated entoconid, unlike the typical morphology of Viverridae.

Kichechia savagei sp. nov. has a wider, longer m1 talonid, and wider, taller p3-4 than Mioprionodon pickfordi (Schmidt-Kittler, 1987). The p3 of Miopr. pickfordi has a clearly marked accessory cuspid, a wide, flat distal cingulum, and a distinct mesial cingulum, all of which are lacking in Ki. savagei sp. nov. The p3-m1 of $K i$. savagei sp. nov. are relatively wider, the $\mathrm{m} 1$ talonid is higher and considerably longer relative to tooth length, and the cuspids are lower and rounder than in Miopr. pickfordi (Schmidt-Kittler, 1987) (Figure 2.4-6).

The m1-2 of Ki. savagei sp. nov. are larger than those of Leptoplesictis rangwai (Schmidt-Kittler, 1987), with a relatively wider and taller talonid. The trigonid cuspids are rounder and less transversely constrained in cross section (Schmidt-Kittler, 1987) (Figure 2.4-6). The $\mathrm{m} 1$ trigonid cuspids of $L$. rangwai vary substantially in height, with the protoconid taller than the paraconid that is much taller than the metaconid. The talonid of the same tooth is significantly lower than any of the trigonid cuspids, and is flatter and more even than those of Ki. savagei sp. nov. (Schmidt-Kittler, 1987: figure 25). The metaconid, protoconid, and paraconid of the $L$. rangwai $\mathrm{m} 2$ talonid are also generally lower than in Ki. savagei sp. nov., (Schmidt-Kittler, 1987) (Figure 2.4-6, 13-15).

Kichechia savagei sp. nov. is substantially smaller than Herpestides aequatorialis (SchmidtKittler, 1987), and its talonid is relatively lower and flatter and the $\mathrm{m} 1$ trigonid considerably higher (Schmidt-Kittler, 1987). The $\mathrm{m} 1$ paraconid of Ki. savagei sp. nov. forms a rounded mesial edge while that of Her. aequatorialis is nearly straight (Schmidt-Kittler, 1987). The heights of the trigonid cusps of the Her. aequatorialis $\mathrm{m} 1$ also vary significantly, with the protoconid being tallest, followed by the paraconid, and then a small, distally leaning metaconid (Schmidt-Kittler, 1987). The heights of the trigonid cusps of $K i$. savagei sp. nov. are nearly equal (Figure 2.1-2, 4-5).

Kichechia savagei sp. nov. has a very slightly taller p3 than p4, which is the opposite of the condition in O. gariepensis (Morales et al., 2001) (Figure 2.1-3, 10-12). Both p3 and p4 have a prominent accessory cuspid distal to the main cuspid, and also a marked mesial and larger distal cingulum 
(Morales et al., 2001). This is true only of p4 in Ki. savagei sp. nov. (Figure 2.1-3, 10-12). The $\mathrm{m} 1$ of $K i$. savagei sp. nov. is taller than that of $O$. gariepensis, the latter taxon also having a high and closed trigonid and more lingually positioned paraconid (Morales et al., 2001) (Figure 2.1-3, 1012). The cuspids of the $m 1$ trigonid are approximately the same height in Ki. savagei sp. nov. (Figure 2.1-2, 4-5, 7-8). The protoconid is tallest in $O$. gariepensis, with the paraconid and metaconid being the same height (Morales et al., 2001). The height of the $\mathrm{m} 1$ talonid is similar to that of Ki. savagei sp. nov. and is taller than the previously compared taxa (Figure 2.1-9). The mesiodistal length of the $\mathrm{m} 1$ talonid of $K i$. savagei sp. nov. relative to the overall length of the tooth is less than that of $O$. gariepensis (Morales et al., 2001) (Table 1). Otherwise, the m1-2 of the two taxa are generally similar (Figure 2.4-6).

Morales and Pickford (2011) posited a new tribe of Paradoxurinae, Kichechiini, to include Kichechia, Orangictis, and Ketketictis, based on the development of robust bunodont dentitions that deviate from the hypercarnivorous morphology represented by Cr. obscurus (Figure 4). They also argued that their dental morphology differs significantly from extant viverrids, e.g., Hemigalinae, Viverrinae, and Genettinae (Morales and Pickford, 2011). The most substantial reported morphological difference concerns the trigonid of $\mathrm{m} 1$ that is noticeably more sectorial in Kichechiini than in Viverrinae (Morales and Pickford, 2011). Morales et al. (2001) also used this difference to distinguish Orangictis from Her. antiquus, considered one of the oldest known members of Viverridae (Hunt, 2001; Morales et al., 2001; Werdelin and Peigné, 2010).

Our revision identifies viverrid fossils at Moruorot and Kalodirr previously assigned to $\mathrm{Ki}$. zamanae to a new species: Ki. savagei sp. nov. Kichechia shares particular morphological traits with known material of Orangictis, primitive Hyaenidae (Protictitherium), and extant Viverrinae (Viverra, Viverricula, Civettictis) (Morales et al., 2001). Though Orangictis and Kichechia have the same generally robust dentition and morphology of the premolars and $\mathrm{m} 1$ trigonid, Kichechia is more primitive (Morales et al., 2001). Kichechia shares a similar talonid structure with Orangictis and hypocarnivorous Viverridae (e.g., Viverra and Civettictis), but other genera (e.g., Genetta and Poiana) and Prionodontidae (Gaubert, 2009) have a simpler talonid that accompanies derived hypercarnivory (Morales et al., 2001).
Further measurements of the referred dental material support the coexistence of Ki. zamanae and Ki. savagei sp. nov. in both Moruorot and Kalodirr, as well as Rusinga. This indicates that regional endemism affected the distribution of small viverrids in eastern Africa during the Early Miocene. This regionalism may be analogous to that seen in Asian and African Herpestidae and Viverridae today (Patou et al., 2008; Wesley-Hunt et al., 2010). In light of this, other viverrid and herpestid records should be revisited to assess additional regional differences. As the fossil record expands, caniforms (Figures 5-6) should likewise be reconsidered to determine the effect of body size, feeding adaptations, and systematic position on species distribution.

Our phylogenetic analysis including Ki. savagei $s p$. nov. resulted in 11 minimum length trees. Each tree had a length of $37, \mathrm{Cl}=0.59$, and $\mathrm{RI}=$ 0.53 . A $50 \%$ majority rule consensus tree of the minimum length trees was generated (Figure 4). In this tree, Ki. savagei sp. nov. was positioned in an unresolved polytomy with Mioparadoxurus meini, Paradoxurus hermaphroditus, and the clade (Pseudocivetta howelli + Tugenictis ngororaensis) (Figure 4). Herpestides is the sister group of this polytomy, with a polytomy of $O$. garienpensis and Ki. zamanae falling outside (Figure 4). In two of the 11 shortest trees, $K i$. savagei sp. nov. and $K i$. zamanae are positioned as sister taxa, while $K i$. savagei sp. nov. was positioned as the sister group to $M$. meini in two trees, and to Ps. howelli in another three trees. This analysis suggests that the addition of Ki. savagei sp. nov. into the Paradoxurinae results in less resolution in the phylogeny of bunodont viverrids, as indicated by the relatively low consistency and retention indices $(\mathrm{Cl}=0.59$, $\mathrm{RI}=0.53$ ). Most notably, the apparent lack of resolution regarding the position of Ki. savagei sp. nov. within the tree likely stems from its high percentage of missing data, along with the substantial missing data in other taxa. Since there is no described maxillary dentition allocated to this species, it can only be scored for 12 of the 25 total characters in the data matrix (Appendix 1). Each of the nodes on the tree is supported by 1 to 4 shared derived characters. Synapomorphies of the nodes (Appendix 2) are indicated below:

Node 1: Character 18: $0 \rightarrow 1$; Node 2: Character 17: $0 \rightarrow 1$; Character 19: $0 \rightarrow 1$; Character 21: $0 \rightarrow 1$; Node 3 : Character 5 : $0 \rightarrow 1$; Character 6 : $0 \rightarrow 1$; Character 14: $0 \rightarrow 1$; Character 20: $0 \rightarrow 1$; Node 4: Character 22: $0 \rightarrow 1$; Character 24: $0 \rightarrow 1$; Node 5: Character 25: $1 \rightarrow 0$. 


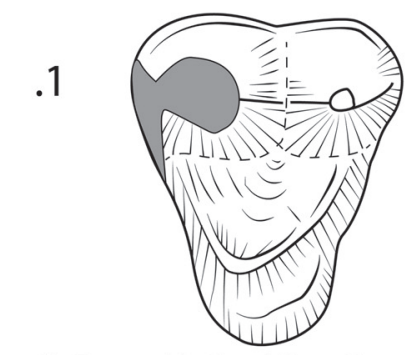

○ The Trustees of the Natural History Museum, London

1. paracone

2. metacone

3. premetacrista

4. postmetacrista

5. metaconule

6. preparacrista

7. postparacrista

8. paraconule

9. protocone
10. trigon basin

11. parastyle

12. cingulum

13. mesial cusp

14. distal cusp

15. metastyle

16. mesial cuspid

17. distal cuspid

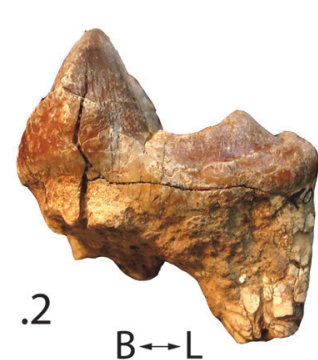

$\mathrm{B} \leftrightarrow \mathrm{L}$

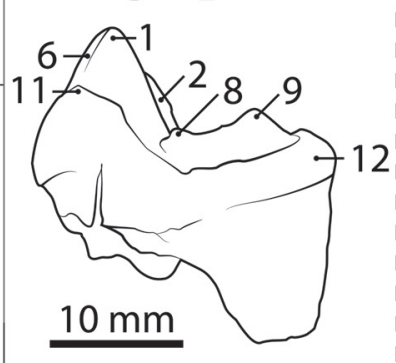

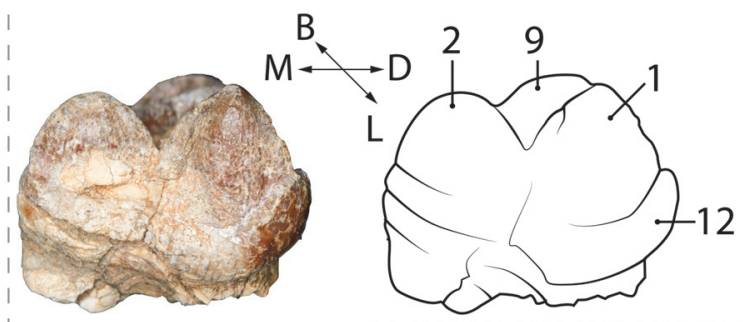

.3

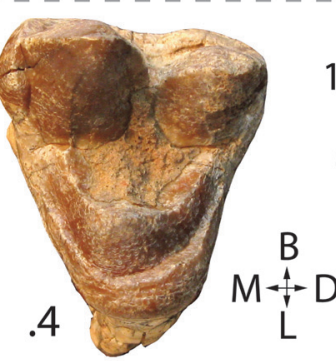

61712

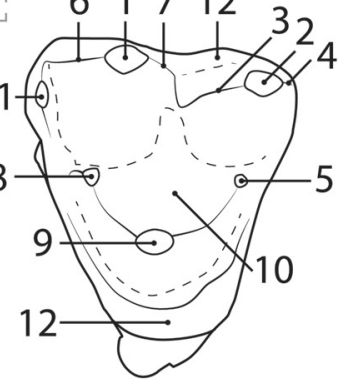

.5
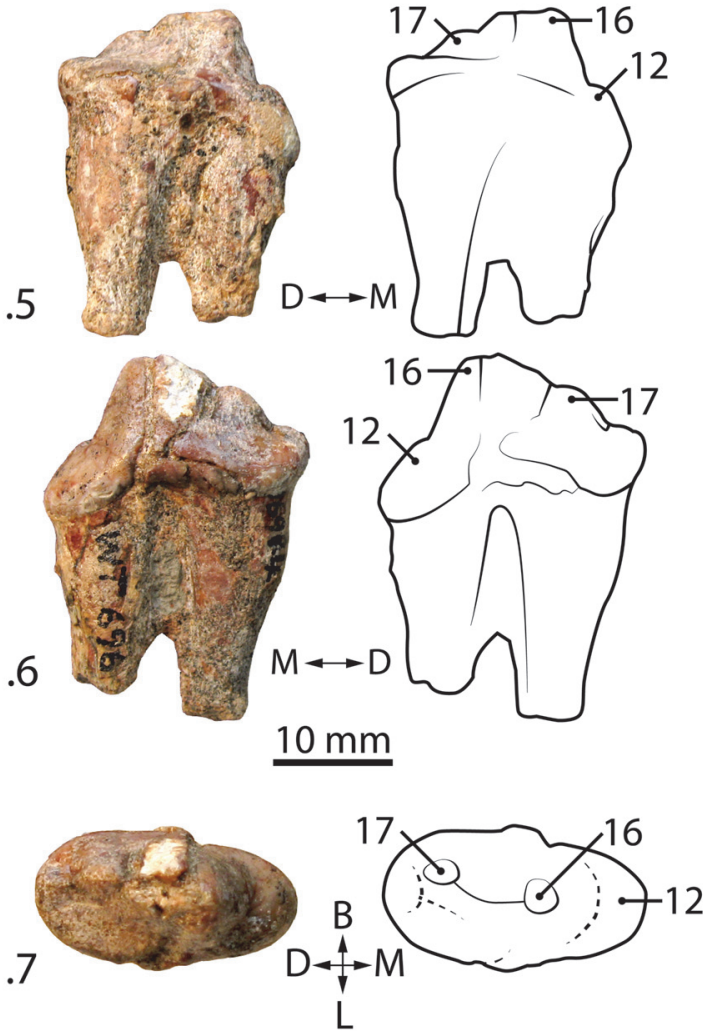
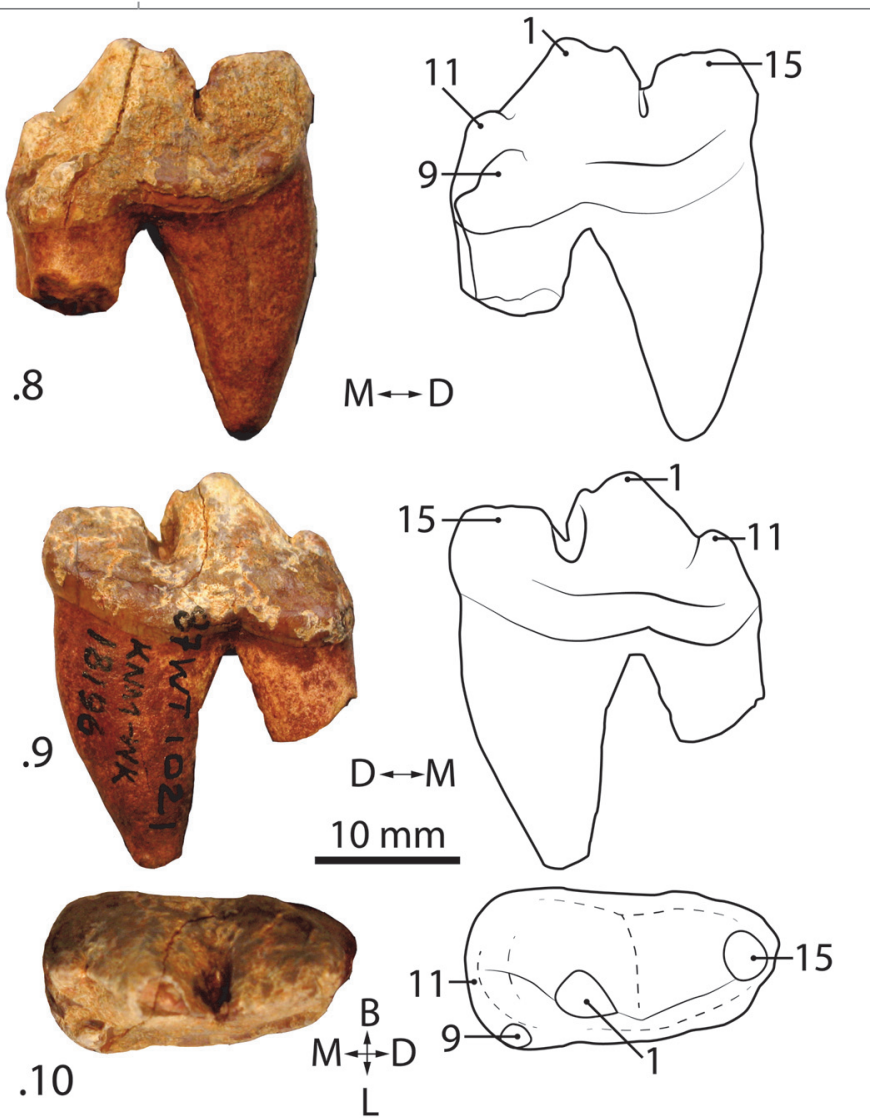

FIGURE 5.1. Cynelos macrodon. Occlusal view of left M1, NHMUK M19086 (Holotype) redrawn after Savage (1965: figure 55). 5.2-4: Mesial (left), mesiolingual (top right), and occlusal (bottom right) views of left M1, KNM-WK17074. 5.5-7: Lingual, buccal, and occlusal views of left p4, KNM-WK16984. 5.8-10: Lingual, buccal, and occlusal views of left P4, KNM-WK18196. 

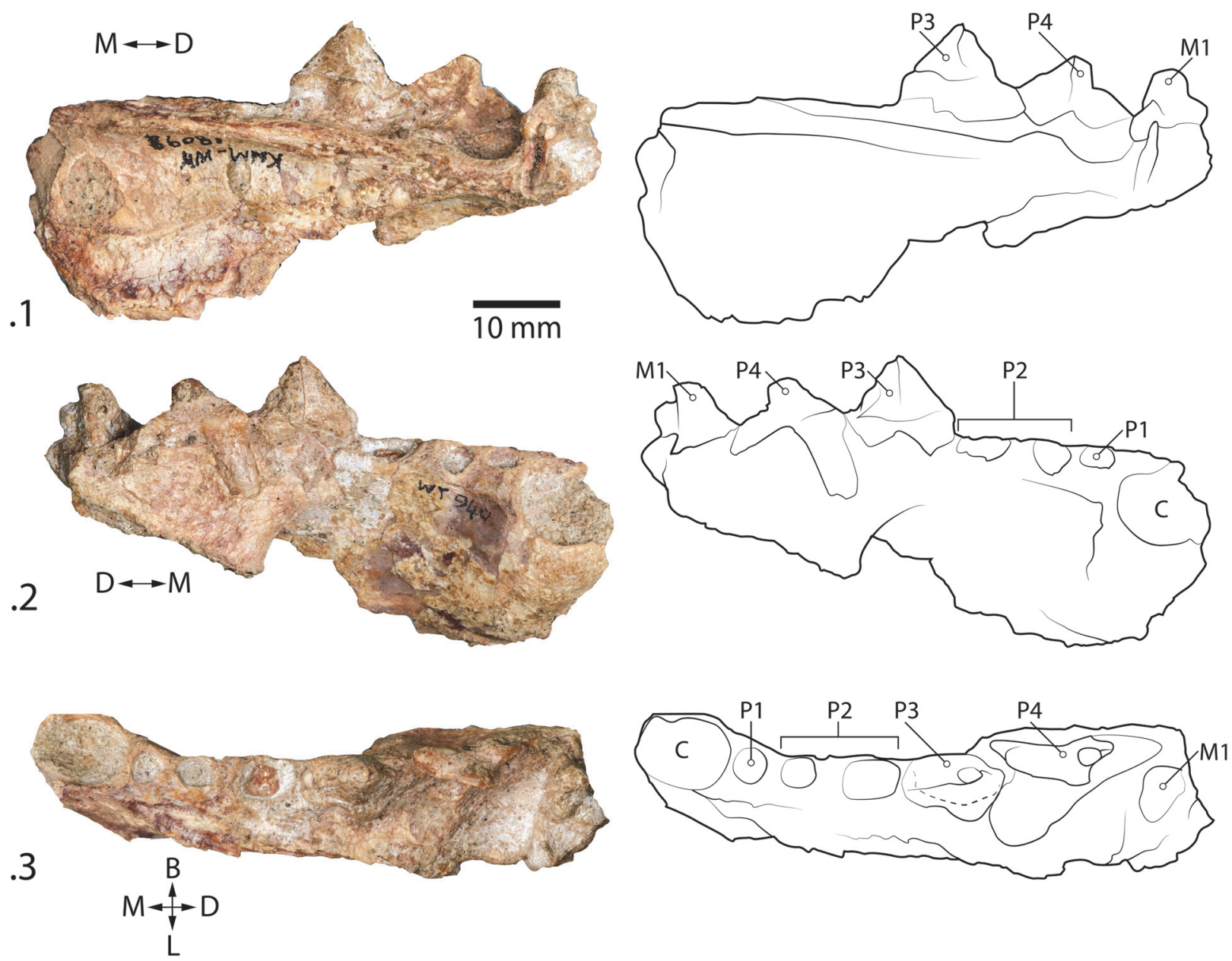

FIGURE 6.1-3. Indeterminate musteloid. (Top to bottom): lingual, buccal, and occlusal views of left maxillary fragment with P3-4, KNM-WK18099.

Thus, the position of Ki. savagei sp. nov. varies greatly between minimum length trees, grouping sometimes with congeneric taxa, but other times with Pseudocivettini. However, it is nonetheless interesting to note that $K i$. savagei sp. nov. is only positioned in a sister taxon relationship with Ki. zamanae in two of the 11 minimum length trees. While this analysis is based solely on dental characters and its implications are consequently limited, it suggests that the genus Kichechia may not be monophyletic. Additionally, the proposed tribe Kichechiini (Kichechia + Orangictis) (Morales and Pickford, 2011) is not supported by this tree, because these taxa do not form a monophyletic group (Figure 4). Future phylogenetic analysis of the Paradoxurinae including additional craniomandibular and dental characters could further resolve these phylogenetic questions.
Family FELIDAE Fischer von Waldheim, 1817 Genus KATIFELIS gen. nov.

Figure 7; Table 2

zoobank.org/31F9346E-A3A3-4308-BD5D-690A79D16068

Type species. Katifelis nightingalei gen. et sp. nov. Derivatio nominis. "Kati" is from Swahili for "intermediate" because of its moderately small size among the contemporary felids.

\section{Katifelis nightingalei gen. et sp. nov.}

Figure 7; Table 2

zoobank.org/2B768C24-A422-4DAE-89B5-2C4E6583EFF5

Type specimen. Left mandibular fragment with $\mathrm{p} 4-$ m1 (KNM-WK17133).

Type locality. Kalodirr, Kalodirr Member, Lothidok Formation, Kenya. Early Miocene.

Age. $17.5 \pm 0.2 \mathrm{Ma}-16.8 \pm 0.2 \mathrm{Ma}$.

Derivatio nominis. The specific name is in honor of Mr. Andrew Nightingale of Kembu Farm in Njoro, 
Kenya, for his many years of support of paleontological and geological research in Kenya.

\section{Diagnosis}

Felidae of relatively small size, slightly smaller than the extant Caracal caracal (Salesa et al., 2012). The $p 4$ is short with minimal accessory cuspid development, except distobuccally (Figure 7). The $\mathrm{m} 1$ paraconid is small relative to the protoconid, as in extant Felidae. The metaconid and $\mathrm{m} 2$ are absent, and the $\mathrm{m} 1$ talonid is low with a small distal cuspid (Figure 7). The p4 accessory cuspids are intermediate between 'Pseudaelurus-' and 'Felis-grade', discussed further below (Werdelin, 2012).

Katifelis gen. nov. differs from the Barbourofelidae by the lack of $\mathrm{m} 1$ metaconid, present in Barbourofelidae, and the presence of the $\mathrm{m} 1$ talonid, lost in Barbourofelidae (Morlo et al., 2004) (Figure 7). The absence of $\mathrm{m} 2$ differs from Proailurus (Filhol, 1881), along with an $\mathrm{m} 1$ protoconid taller than paraconid, though both have lost the metaconid (Werdelin, 2012). Differs from Styriofelis (Kretzoi, 1929), by a substantially taller $\mathrm{m} 1$ protoconid than paraconid. The $\mathrm{m} 1$ protoconid is also more vertically inclined in Katifelis gen. nov. and has a broader talonid (Werdelin, 2012; Robles et al., 2013). Differs from Asilifelis in substantially larger size and more robust dentition (Werdelin, 2012).

\section{Description}

Katifelis nightingalei gen. et sp. nov. possesses a relatively gracile mandible with a corpus height of $12.5 \mathrm{~mm}$ at the level of the p4. Both p4 and $\mathrm{m} 1$ are nearly complete, missing only perhaps the tip of the mesial accessory cuspid of p4 (Figure 7). The mesiobuccal end of the $\mathrm{m} 1$ overlaps slightly with the distolingual end of the $\mathrm{p} 4$, forming a slight imbrication (Figure 7.2-3). The $\mathrm{m} 1$ has a very tall protoconid, a slightly lower paraconid, and no discernable metaconid (Figure 7.1-3). The talonid basin is low, narrow, quadrangular, and flat (Figure 7). There is a very low talonid cuspid (Figure 7.1-2), the preprotocristid is well defined to form a distinct buccal shearing edge, and the postprotocristid forms a broad slope lingually (Figure 7). There are no apparent cingula on its lingual or buccal aspects (Figure 7.2-3). The main cusp of the p4 is substantially taller than any other feature of the tooth and also taller than the $\mathrm{m} 1$ paraconid (Figure 7.1-2). There is a small mesial accessory cuspid on p4, which is lower than the distal accessory cuspid (Figure 7.1-2). Between the main cus- pid and distal accessory cuspid, there is a distinct notch on the buccal aspect (Figure 7.2). The distal accessory cuspid terminates in a small distal cingulum (Figure 7.2-3).

In the Burdigalian (from $20.43 \pm 0.05 \mathrm{Ma}$ to $15.97 \pm 0.05 \mathrm{Ma}$ ), felids of 'Pseudaelurus-grade' (Pseudaelurus, Styriofelis, Hyperailurictis) diverge in Eurasia and North America (Werdelin et al., 2010; Werdelin, 2012). Near the beginning of the Tortonian (11.6 Ma), significantly younger felids of 'Felis-grade' appear (Werdelin, 2012). Katifelis nightingalei gen. et sp. nov. is smaller than Styriofelis and Pseudaelurus (both of 'pseudaelurinegrade') (Werdelin and Peigné, 2010; Werdelin, 2012) and is quite different from all described Early and Middle Miocene Felidae (Werdelin and Peigné, 2010; Wesley-Hunt et al., 2010; Leakey et al., 2011; Morales and Pickford, 2011; Salesa et al, 2012; Werdelin, 2012; Robles et al., 2013). It is smaller than Diamantofelis ferox (Morales et al., 1998) and Namafelis minor (Morales et al., 2003), but larger than Asilifelis coteae (Morales et al., 1998; Morales et al., 2003; Werdelin and Peigné, 2010; Werdelin, 2012). Among the Felidae, N. minor from Arrisdrift in Namibia exhibits a posterior cingulum on the $\mathrm{m} 1$ talonid not seen in Katifelis (Morales et al., 2003). It further differs from Namafelis by having a more slender $\mathrm{m} 1$ and less developed accessory cuspids on p4 (compare Figure 7 herein with plate 7 , figure 5 in Morales et al. [2003]). The mandible of $K a$. nightingalei gen. et sp.nov. is considerably dorsoventrally lower than that of Diamantofelis, with a taller $\mathrm{m} 1$ protoconid relative to paraconid, and lower p4 main cuspid than $\mathrm{m} 1$ protoconid (Morales et al., 1998). Its p4 and $\mathrm{m} 1$ cuspids are more rounded, and it has a more gently sloped $\mathrm{m} 1$ postprotocristid than Asilifelis (Werdelin, 2012).

Suborder CANIFORMIA Kretzoi, 1943 Infraorder ARCTOIDEA Flower, 1869

Family AMPHICYONIDAE Trouessart, 1885

Subfamily AMPHICYONINAE Hunt, 1998

Genus CYNELOS Jourdan, 1862

Cynelos macrodon (Savage, 1965)

Figure 5; Table 3

Holotype. Left M1 (NHMUK M19086; Savage 1965).

Synonymy. Hecubides macrodon (Savage, 1965). Type locality. Site 31, Rusinga Island, Kiahera Formation, Kenya. Early Miocene.

Geographic occurrence. Kenya (Bishop and Clark, 1965; Leakey and Leakey, 1986a), Uganda (Savage, 1965), Egypt (Fourtau, 1918; Morlo et al., 2007). 

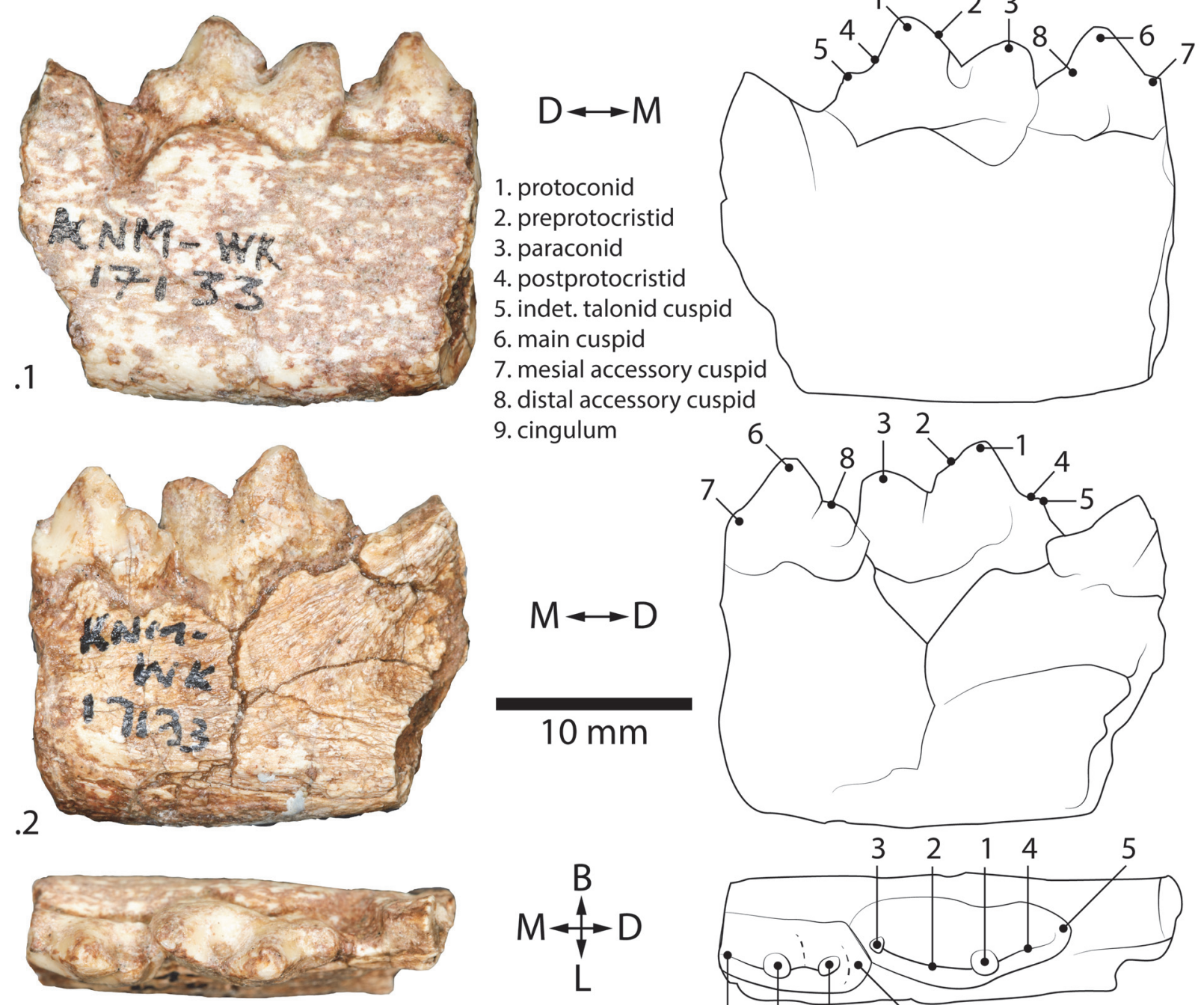

9. cingulum

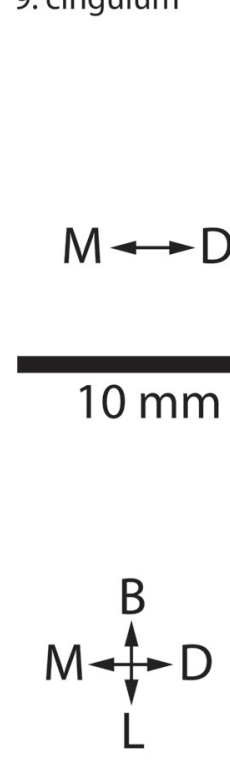

.3

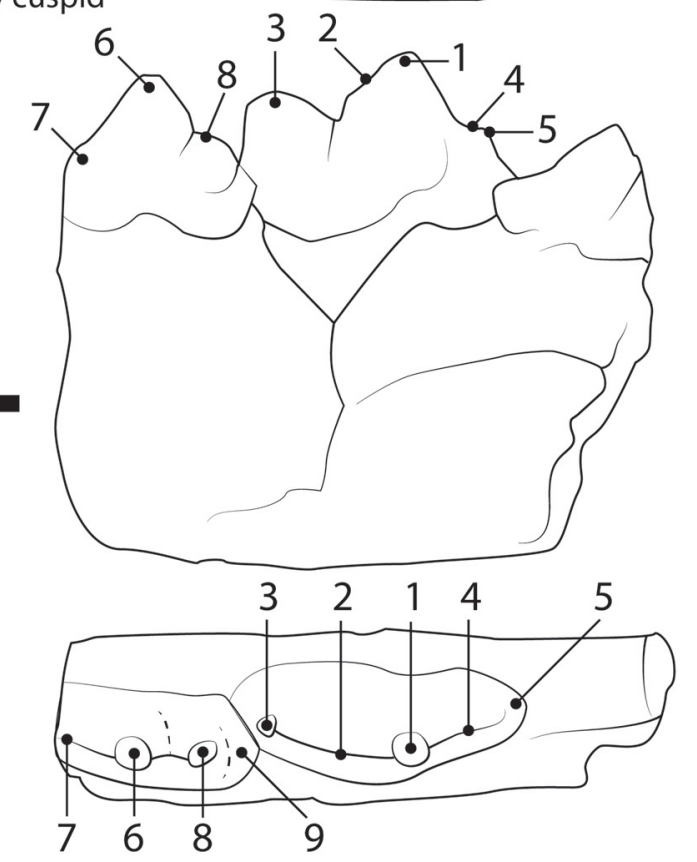

FIGURE 7.1-3. Katifelis nightingalei gen. et sp. nov. (Top to bottom): lingual, buccal, and occlusal views of left maxillary fragment, KNM-WK17133.

Referred specimens. Left P4 (KNM-WK18196); left p4 (KNM-WK16984); left M1 (KNM-WK17074). Age. $\sim 20 \mathrm{Ma}-17 \mathrm{Ma}$.

\section{Description}

Specimen KNM-WK17074 is a left M1 that is broad buccolingually and has a paracone that is much taller and more pointed than the other cusps (Figure 5.2-4). A distinct shearing preparacrista descends mesially to a low and clearly defined parastyle (Figure 5.2, 4). The parastyle is very slightly taller than the protocone (Figure 5.2) that encompasses a broad trigon basin rising gently lingually (Figure 5.2, 4). A small metaconule (Figure 5.4) and paraconule (Figure 5.2-4) are also present on the lingual bases of their respective cusps.
There is a wide cingulum wrapping around the entire lingual edge of the protocone (Figure 5.2-4). Both roots are damaged; the buccal root is broken at the cervix and the lingual root is missing approximately the deepest third of its tip (Figure 5.2).

Specimen KNM-WK16984 is a left $\mathrm{p} 4$. Its main (mesial) cuspid is tall and rounded, and the accessory (distal) cuspid is lower, gently sloping to a wide distal cingulum (Figure 5.5-7). The mesial edge of the main cuspid forms a steep shearing edge and terminates lower than the rounded distal cingulum (Figure 5.5-6). Approximately one third of each root is broken, with the distal root extending slightly further (Figure 5.5-6).

Specimen KNM-WK18196 is a left P4, with a deep notch separating the paracone from the 
TABLE 2. Measurements (in $\mathrm{mm}$ ) of discussed Felidae lower dentitions. All other measurements are by the authors.

\begin{tabular}{lllcccc}
\hline \multicolumn{1}{c}{ Taxon } & \multicolumn{1}{c}{ Site } & Specimen & Lm1 & Wm1 & Lp4 & Wp4 \\
\hline Katifelis nightingalei gen. et sp. nov. & Kalodirr & KNM-WK17133 & 9.8 & 3.7 & 7.0 & 3.4 \\
Asilifelis coteae & Rusinga & KNM-RU18349 & 7.4 & 2.8 & 5.5 & 2.4 \\
Namafelis minor & Arrisdrift & AD 99'95 & 11.5 & 4.8 & 9.0 & 4.3 \\
Diamantofelis ferox & Arrisdrift & AD 98'95 & 15.2 & 6.3 & 12.6 & 6.0 \\
Styriofelis turnauensis & Vallès-Penedès & IPS41970 & 11.3 & 4.9 & --- & -- \\
& Vallès-Penedès & IPS42169 & 11.3 & 5.1 & -- & -- \\
Pseudaelurus romieviensis & Vallès-Penedès & IPS41973 & -- & -- & 12.8 & 6.3 \\
& Vallès-Penedès & IPS42063 & 16.3 & 7.5 & 12.8 & 6.3 \\
& Vallès-Penedès & IPS60891 & --- & --- & 13.8 & 6.3 \\
Pseudaelurus quadridentatus & Vallès-Penedès & IPS60892b & 18.0 & 7.8 & --- & --- \\
& Vallès-Penedès & IPS60892C & 18.0 & 7.9 & 13.9 & 6.7 \\
\hline
\end{tabular}

slightly lower, flat metastyle (Figure 5.8-10). There is a wide cingulum that is significantly lower than the main and accessory cusps, and wraps along the mesial, buccal, and lingual aspects of the tooth (Figure 5.8-10). The distal root is intact, and the mesial root is broken approximately halfway along its length (Figure 5.8-9).

\section{Discussion}

Savage (1965) described Hecubides, a new genus to include the new amphicyonine species Hec. euryodon. In the same publication, he also described a larger species, Hec. macrodon. Schmidt-Kittler (1987) described additional material from both species and considered Hec. euryodon similar enough to the European Cynelos lemanensis to synonymize the two genera.

Morales and Pickford (2008) described a third, smaller species, Hec. minor. Considerable controversy still exists regarding whether Hecubides and Cynelos should be considered distinct, with Morales and Pickford (2008) favoring separate genera and Werdelin and Peigné (2010) favoring synonymy. The referred material here is assigned to Cynelos. Considering that it is larger than both $C y$. euryodon and Cy. minor, with more rounded and subtle features than $C y$. euryodon, it is assigned to $C y$. macrodon (Table 3). The material presented here is also morphologically close to the holotype NHMUK M19086 (Figure 5.1) (Savage, 1967; figure 55), with a wider paracone than metacone on the M1 (unlike in Cy. euryodon) (Figure 5.3-4). The protocone is low, broad, and crescentic (Figure 5.2-4). The M1 also has cingula that are well developed lingually (though proportionally smaller than in Cy. euryodon) and extremely thin along the buccal edge of the paracone and metacone (Figure 5.1-4). In addition to aligning strongly to the holotype, this study contributes new descriptions and measurements of p4 and P4 (Table 3).

$$
\begin{gathered}
\text { Superfamily MUSTELOIDEA Fischer von } \\
\text { Waldheim, } 1817 \\
\text { Family indet. } \\
\text { Figure } 6
\end{gathered}
$$

\begin{tabular}{|c|c|c|c|c|c|c|c|}
\hline Taxon & Specimen & L P4 & W P4 & L M1 & W M1 & L p4 & W p4 \\
\hline \multirow[t]{5}{*}{ Cynelos macrodon } & KNM-WK18196 & 21.1 & 11.0 & --- & --- & --- & --- \\
\hline & KNM-WK16984 & --- & --- & --- & --- & 21.1 & 11.6 \\
\hline & KNM-WK17074 & --- & --- & 22.7 & 20.4 & --- & --- \\
\hline & KNM-RU2957 & --- & --- & 18.3 & --- & --- & --- \\
\hline & NHMUK M19086 & --- & --- & 20.5 & 24.2 & --- & --- \\
\hline \multirow[t]{2}{*}{ Cynelos euryodon } & CA-314 & --- & --- & 17.1 & 20.0 & --- & --- \\
\hline & NHMUK M19084 & 17.5 & 10.3 & 14.6 & 17.5 & --- & --- \\
\hline
\end{tabular}

TABLE 3. Measurements (in mm) of amphicyonid cheek teeth; for Cynelos macrodon (NHMUK M19086) and Cynelos euryodon (NHMUK M19084) after Savage (1965); for Cynelos euryodon (CA-314) after Schmidt-Kittler (1987). All other measurements are by the authors. 
Locality. Kalodirr, Kalodirr Member, Lothidok Formation, Kenya. Early Miocene.

Geographic occurrence. Kenya.

Referred specimen. Left maxillary fragment with P3-4 (KNM-WK18099).

Age. $17.5 \pm 0.2 \mathrm{Ma}-16.8 \pm 0.2 \mathrm{Ma}$.

\section{Description}

There is a marked alveolus for a large canine, the alveoli for a small, single-rooted P1 and a double-rooted P2 (including a distal root fragment), a nearly complete $\mathrm{P} 3$, the partial buccal edge of P4, and a heavily damaged partial M1, for which the crown shape cannot be determined (Figure 6). A remnant of the palatine process of the maxilla is intact, extending from the middle of the alveolus of the canine to the remains of the buccal shearing surface of P4 (Figure 6.1, 3). A degraded depression lingual to $\mathrm{P} 4$ suggests that it was a wide tooth (Figure 6.3). The P3 is triangular and nearly symmetrical in lateral profile, with a prominent lingual protrusion (Figure 6.1-3). A distinct cingulum extends the entire length of the tooth on its lingual aspect (Figure 6.1, 3).

\section{Discussion}

The short pre-carnassial dentition indicates that this specimen belongs to Musteloidea. Only Herpestidae would potentially have such a short splanchnocranium, but this specimen is far larger than any known herpestid. The M1 is not complete, with an unknown distal portion sheared off such that the morphology, particularly the distinction between tooth and bone of the damaged M1 is unclear. This has left a triangular remnant, whereas the complete tooth could be rhombic or rectangular. The triangular shape shown (Figure 6) indicates the extent of the enamel. KNM-WK18099 is approximately twice the size of any known Early Miocene herpestid from Africa. The very large protocone of the $\mathrm{P} 4$, disproportionately large canine, and exceptionally short diastemata between C, P1, and $\mathrm{P} 2$ also substantiate a musteloid rather than herpestid identity. Due to the damage and fragmentary nature of the specimen, it cannot be assigned to a family or a genus. An identification at family or lower rank would require more complete material.
Luogale is the only known musteloid at Rusinga (Schmidt-Kittler, 1987; Morales et al., 2000). Comparatively, the Kalodirr specimen is approximately twice its size, has a more gradually sloping mesial edge of the P4 protocone, and a more bladelike shearing buccal surface of the P3 (Figure 6.1-2). This specimen is the only musteloid known from the Turkana Basin at this time, hinting at a more diverse carnivoran guild, especially among musteloids.

\section{CONCLUSIONS}

Carnivora found in the Lothidok formation include Kichechia savagei sp. nov., Katifelis nightingalei gen. et. sp. nov., Cynelos macrodon, and an unnamed musteloid. Of these, two are present in other sites: Cy. macrodon and Ki. savagei sp. nov. are also found at Rusinga (Table 3). However, the two remaining species, Katifelis nightingalei gen. et sp. nov., and Musteloidea indet., are thus far unique to the Lothidok Formation. This level of regional endemism is similar to that observed among other groups such as primates (Leakey et al. 1986a, b), rodents (Grossman et al., 2014), macroscelids, reptiles (Grossman and Holroyd, 2009), and ungulates (Grossman and Solounias, 2014). Taken together, these specimens emphasize an increased diversity of known African Early Miocene carnivorans. Our results do not support the grouping of Kichechia, O. gariepensis, and provisionally Ketketictis (Morlo et al., 2007) as belonging to the tribe Kichechiini (Morales and Pickford, 2011). Furthermore, these fossils underscore the importance of regional differences as we reconstruct past environments and highlight the need for further collecting in the Early Miocene of the Turkana Basin and other less studied regions.

\section{ACKNOWLEDGMENTS}

BA would like to thank Dr. H.F. Smith for her helpful consultation regarding the statistics in this study. LW acknowledges support from the Swedish Research Council (VR). AG was supported by the Leakey Foundation. We appreciate the careful attention from the referees of this study.

\section{REFERENCES}

Anyonge, W. 1991. Fauna from a new lower Miocene locality west of Lake Turkana, Kenya. Journal of Vertebrate Paleontology, 11:378-390. https://doi.org/10.1080/ 02724634.1991.10011405 
Bishop, W.W. and Clark, J.D. (eds.) 1965. Background to Evolution in Africa. University of Chicago Press, Chicago.

Boschetto, H.B., Brown, H.F., and McDougall, I. 1992. Stratigraphy of the Lothidok Range, northern Kenya, and K/Ar Ages of its Miocene primates. Journal of Human Evolution, 22:4771. https://doi.org/10.1016/0047-2484(92)90029-9

Bowditch, T.E. 1821. An Analysis of the Natural Classification of Mammalia for the Use of Students and Travelers. J. Smith, Paris.

Collinson, M.E., Andrews, P., and Bamford, M.K. 2009. Taphonomy of the early Miocene flora, Hiwegi Formation, Rusinga Island, Kenya. Journal of Human Evolution, 57:149-162. https:// doi.org/10.1016/j.jhevol.2009.02.010

Flower, W.H. 1869. On the value of the characters of the base of the cranium in the classification of the order Carnivora, and on the systematic position of Bassaris and other disputed forms. Proceedings of the Zoological Society of London, 37: 4-37. https://doi.org/10.1111/j.14697998.1869.tb07286.x

Filhol M.H. 1881. Étude des mammifères fossiles de Saint-Gérand-le-Puy (Allier). Volume 2.. Masson, Paris.

Fischer von Waldheim, G. 1817. Adversaria Zoologica, fasciculus primus. Mémoires de la Société impériale des Naturalistes de Moscou, 5:357-446.

Fourtau, R. 1918. Contribution à l'Étude des Vertébrés Miocènes de l'Égypte. Survey Department, Ministry of Finance, Egypt Government Press, Cairo.

Gaubert, P. 2009. Family Prionodontidae (Linsangs), p. 170-173. In Wilson, D.E. and Mittermeier, R.A. (eds.), Handbook of Mammals of the World. Vol. 1: Carnivores. Lynx Edicions, Barcelona.

Goboloff, P.A. and Catalano, S.A. 2016. TNT version 1.5, including a full implementation of phylogenetic morphometrics. Cladistics, 32:221-238. https://doi.org/10.1111/cla.12160

Gray, J.E. 1821. On the natural arrangement of vertebrose animals. The London Medical Repository, 15:296-310.

Gray, J.E. 1864. A revision of the genera and species of viverrine animals (Viverridae), founded on the collection in the British Museum. Proceedings of the Zoological Society of London, 1864: 502-579. https://archive.org/details/biostor-104564

Grossman, A. and Holroyd, P.A. 2009. Miosengi butleri, gen. et sp. nov. (Macroscelidea) from the Kalodirr Member, Lothidok Formation, early Miocene of Kenya. Journal of Vertebrate Paleontology, 29:957-960. https://doi.org/10.1671/039.029.0318

Grossman, A., Liutkus-Pierce, C., Kyongo B., and M'Kirera, F. 2014. New fauna from Loperot contributes to the understanding of Early Miocene catarrhine communities.International Journal of Primatology, 35:1253-1274. https://doi.org/10.1007/s10764-014-9799-8

Grossman, A. and Solounias, N. 2014. New fossils of Giraffoidea (Mammalia: Artiodactyla) from the Lothidok Formation (Kalodirr Member, Early Miocene, West Turkana, Kenya) contribute to our understanding of early giraffoid diversity. Zitteliana, 24:63-70.

Hill, A., Nengo, I.O., and Rossie, J.B. 2013. A Rangwapithecus gordoni mandible from the Early Miocene site of Songhor, Kenya. Journal of Human Evolution, 65:490-500. https://doi.org/ 10.1016/j.jhevol.2013.02.014

Hunt, R.M., Jr. 1998. Ursidae, p. 174-195. In Janis, C.M., Scott, K.M., and Jacobs, L.L. (eds.), Evolution of Tertiary Mammals of North America: Volume 1, Terrestrial Carnivores, Ungulates, and Ungulate like Mammals. Cambridge University Press, Cambridge.

Hunt, R.M., Jr. 2001. Small Oligocene amphicyonids from North America (Paradaphoenus, Mammalia, Carnivora). American Museum Novitates, 3331:1-20. https://doi.org/10.1206/ 0003-0082(2001)331<0001:SOAFNA>2.0.CO;2

Jourdan, C. 1862. Description de restes fossiles de grands mammifères. Revue des Sociétés Savantes, 1:126-130.

Kretzoi, M. 1929. Materialen zur phylogenetischen Klassifikation der Aerloideen. International Congress of Zoology Budapest, 10:1293-1355.

Kretzoi, M. 1943. Kochictis centennii n. g. n. sp., in alterümlicher Creodonte aus dem Oberoligozän Sienbenbürgens. Földtani Közlöny, 73:190-195.

Kretzoi, M. 1945. Bemerkungen über das Raubtiersystem. Annales historico-naturales Musei nationalis hungarici, 38:59-83.

Leakey, R.E. and Leakey, M.G. 1986a. A new Miocene hominoid from Kenya. Nature, 324:143146. https://doi.org/10.1038/324143a0 
Leakey, R.E. and Leakey, M.G. 1986b. A second new Miocene hominoid from Kenya. Nature, 324:146-148. https://doi.org/10.1038/324146a0

Leakey, M.G., Grossman, A., Gutiérrez, M., and Fleagle, J.G. 2011. Faunal Change in the Turkana Basin during the Late Oligocene and Miocene. Evolutionary Biology, 20:238-253. https://doi.org/10.1002/evan.20338

Madden, C.T. 1972. Miocene mammals, stratigraphy and environment of Muruarot Hill, Kenya. PaleoBios, 14:1-12.

Maxbauer, D.P., Peppe, D.J., Bamford, M., McNulty, K.P., Harcourt-Smith, W.E.H., and Davis, L.E. 2013. A morphotype catalog and paleoenvironmental interpretations of early Miocene fossil leaves from the Hiwegi Formation, Rusinga Island, Lake Victoria, Kenya.

Palaeontologia Electronica, 16:28A. https://doi.org/10.26879/342 http://palaeo-electronica.org/content/2013/547-rusinga-island-flora

Morales, J. and Pickford, M. 2008. Creodonts and carnivores from the Middle Miocene Muruyur Formation at Kipsaraman and Cheparawa, Baringo District, Kenya. Comptes Rendus Palevol, 7:487-497. https://doi.org/10.1016/j.crpv.2008.09.011

Morales, J. and Pickford, M. 2011. A new paradoxurine carnivore from the Lake Miocene Siwaliks of India and a review of the bunodont viverrids of Africa. Geobios, 44:271-277.

Morales, J., Pickford, M., Fraile, S., Salesa, M.J., and Soria, D. 2003. Creodonta and Carnivora from Arrisdrift, early Middle Miocene of Southern Namibia. Memoirs of the Geological Survey of Namibia, 19:177-194. https://doi.org/10.1016/j.geobios.2011.02.001

Morales, J., Pickford, M., Salesa, M., and Soria, D. 2000. The systematic status of Kelba, Savage, 1965, Kenyalutra, Schmidt-Kittler, 1987 and Ndamathaia, Jacobs et al., 1987, (Viverridae, Mammalia) and a review of Early Miocene mongoose-like carnivores of Africa. Annales de Paléontologie, 86:243-251. https://doi.org/10.1016/S0753-3969(01)80002-1

Morales, J., Pickford, M., Soria, D., and Fraile, S. 1998. New carnivores from the basal Middle Miocene of Arrisdrift, Namibia. Eclogae Geologicae Helvetiae, 91:27-40. http://doi.org/ $10.5169 /$ seals- 168406

Morales, J., Pickford, M., Soria, D., and Fraile, S. 2001. New Viverrinae (Carnivora: Mammalia) from the basal Middle Miocene of Arrisdrift, Namibia. Paleontology of Africa, 37:99-102.

Morlo, M., Miller, E.R., and El-Barkooky, A.N. 2007. Creodonta and Carnivora from Wadi Moghra, Egypt. Journal of Vertebrate Paleontology, 27:145-159. https://doi.org/10.1671/ 0272-4634(2007)27[145:CACFWM]2.0.CO;2

Morlo, M., Peigné, S., and Nagel, D. 2004. A new species of Prosansanosmilus: implications for the systematic relationships of the family Barbourofelidae new rank (Carnivora, Mammalia). Zoological Journal of the Linnean Society, 140:43-61. https://doi.org/10.1111/j.10963642.2004.00087.x

Patou, M.-L., Debruyne, R., Jennings, A.P., Zubaid, A., Rovie-Ryan, J.J., and Veron, G. 2008. Phylogenetic relationships of the Asian palm civets (Hemigalinae \& Paradoxurinae, Viverridae, Carnivora). Molecular Phylogenetics and Evolution, 47:883-892. https://doi.org/ 10.1016/j.ympev.2008.03.026

Peppe, D.J., Deino, A.L., McNulty, K.P., McCollum, M.S., Mitchell, A.L., Driese, S.G., Dunsworth, H.M., Fox, D.L., Harcourt-Smith, W.E., Jenkins, K., Lehmann, T., and Michel, L.A. 2017. Revised geochronology of the Early Miocene faunas from Rusinga Island and Mfangano Island (Lake Victoria, Kenya): implications for Miocene hominoid evolution and faunal succession. American Journal of Physical Anthropology, 162:313.

Rasmussen, D.T. and Gutiérrez, M. 2009. A mammalian fauna from the late Oligocene of northwestern Kenya. Palaeontographica Abteilung A, 288:1-52. https://doi.org/10.1127/pala/ 288/2009/1

Reynoso, D.E. 2014. New early Miocene ${ }^{40} \mathrm{Ar} /{ }^{39} \mathrm{Ar}$ ages for Nakwai, northwest Kenya, Africa, and Paleontological analysis of Meroëhyrax kyongoi dentition. UNLV Theses, Dissertations, Professional Papers, and Capstones, 2290. https://digitalscholarship.unlv.edu/thesesdissertations/2290

Robles, J.M., Madurell-Malapeira, J., Abella, J., Rotgers, C., Carmona, R., Almécija, S., Balaguer, J., and Alba D.M. 2013. New Pseudaelurus and Styriofelis remains (Carnivora: Felidae) from the Middle Miocene of Abocador de Can Mata (Vallès-Penedès Basin). Comptes Rendus Palevol, 12:101-113. https://doi.org/10.1016/j.crpv.2013.02.001

Salesa, M.J., Antón, M., Morales, J., and Peigné, S. 2012. Systematics and phylogeny of the small felines (Carnivora, Felidae) from the Late Miocene of Europe: a new species of Felinae 
from the Vallesian of Batallones (MN 10, Madrid, Spain). Journal of Systematic Palaeontology, 10:87-102. https://doi.org/10.1080/14772019.2011.566584

Savage, R.J.G. 1965. Fossil Mammals of Africa: 19: The Miocene Carnivora of East Africa, Bulletin of the British Museum (Natural History) Geology, 10:239-316. http://direct.biostor.org/ reference/118744

Schmidt-Kittler, N. 1987. The Carnivora (Fissipedia) from the Lower Miocene of East Africa. Palaeontographica, Abt. A, 197:85-126.

Trouessart, E-L. 1885. Catalogue des mammifères vivants et fossiles (Carnivores). Bulletin de la Société d'Études Scientifiques d'Angers, supplément à l'année 1884:1-108. https://doi.org/ 10.5962/bhl.title.63808

Werdelin, L. 2012. A new genus and species of Felidae (Mammalia) from Rusinga Island, Kenya, with notes on early Felidae of Africa. Estudios Geológicos, 67:217-222. https://doi.org/ 10.3989/egeol.40480.185

Werdelin, L. and Peigné, S. 2010. Carnivora, p. 603-657. In Werdelin, L. and Sanders, W.J. (eds.), Cenozoic Mammals of Africa. University of California Press, Berkeley. https://doi.org/ 10.1525/california/9780520257214.001.0001

Wesley-Hunt, G.D., Dehghani, R., and Werdelin, L. 2010. Comparative ecomorphology and biogeography of Herpestidae and Viverridae (Carnivora), p. 246-268. In Goswami, A. and Friscia, A. (eds.), Carnivoran Evolution: New Views on Phylogeny, Form, and Function. Cambridge University Press, Cambridge. 
Adrian, Werdelin, \& Grossman: NeW Kenyan Miocene Carnivora

\section{APPENDIX 1.}

Modified dental character matrix from Morales and Pickford (2011), with Kichechia savagei sp. nov. added. This includes extant and fossil viverrid and herpestid species.

Kichechia zamanae

Kichechia savagei sp. nov.

Ketketictis solida

Tugenictis ngororaensis

Herpestides aequatorialis

Paradoxurus hermaphroditus

Mioparadoxurus meini

Pseudocivetta ingens

Orangictis gariepensis

Crossarchus obscurus
0111001110110000111010111

?????????????100001011111

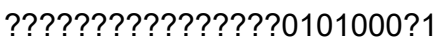

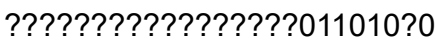

??11111??????1???1011000?

1010111111101111101111011

???????????010?1011110?1

??10110011111001111111110

????????????0001111010000

1111001110010000000000000 


\section{APPENDIX 2.}

Characters and dental states of lower dentition from selected species of Viverridae and Herpestidae, modified from Morales and Pickford (2011; appendix A).

\section{Upper dentition}

P3

1. Protocone; absence (0) presence (1)

2. Development of the metastyle (posterior cusplet); present (0) reduced (1)

\section{P4}

3. Occludal morphology; enlongated (0) short, triangular (1)

4. Size of the parastyle; absent or very small (0) strong (1)

5. Morphology of the metastyle; sectorial (0) bunodont (1)

6. Size of the protocone; medium sized (0) very developed (1)

7. Separation protocone-paracone; close (0) very separated (1)

\section{M1}

8. Development of the stylar area; moderate (0) very developed (1)

9. Morphology of the trigon valley; open (0) closed anteriorly (1)

10. Size and morphology of the protocone; conical, moderate size (0) bunodont, strong (1)

11. Morphology and size of the parastyle; sectorial, strong (1) reduced, non-sectorial (1)

M2

12. Size with respect to M1; small (0) big (1)

\section{Lower dentition}

p4

13. Height of the protoconid; high (0) low (1)

14. Size of the paraconid; weak (0) strong (1)

15. Development of the metaconid; absent (0) present (1)

16. Development of the entoconid; absent (0) present (1)

17. Development of a valley in the talonid; absent (0) present (1)

m1

18. Connection metaconid-protoconid; united by cristids (0) separated (1)

19. Height of the trigonid; high (0) low (1)

20. Morphology of the cusps in the trigonid-talonid; sectorial and/or sharp (0) bunodont (1)

21. Morphology of the posterior wall of the trigonid; vertical (0) inclined and with a recess in the trigonid valley (1)

22. Entoconid; absent (0) present (1)

23. Pre-entoconid; absent (0) present (1)

m2

24. Trigonid morphology; trigonid complete (0) reduction of cusplets (1)

25. Position of the metaconid in $\mathrm{m} 1$; more anterior than the protoconid $(0)$ retired (1) 